\title{
Infective respiratory exacerbations in young adults with cystic fibrosis: role of viruses and atypical microorganisms
}

\author{
E L C ONG, M E ELLIS, A K WEBB, K R NEAL, MARY DODD, E O CAUL, \\ S BURGESS
}

From the Regional Department of Infectious Diseases and Tropical Medicine and the Adult Cystic Fibrosis Unit, Monsall Hospital, Manchester, and the Public Health Laboratory, Bristol

ABSTRACT Thirty six adults with cystic fibrosis were studied over one year to determine the incidence of infection with respiratory viruses and atypical organisms. Nineteen patients entered the study during an acute exacerbation of respiratory symptoms with an increase in purulent sputum production, cough, or breathlessness accompanied by a fall in $\mathrm{FEV}_{1}$ (group 1); 17 patients entered when they were stable both clinically and in terms of lung function values (group 2). Group 1 patients had a mean of 2.6 (range 1-4) infective exacerbations during the year and group 2 patients a mean of $1 \cdot 1(0-2)$ exacerbations. Eleven patients developed serological evidence of viral (influenza virus $A$ and B, cytomegalovirus, human rhinovirus 2, adenovirus) or Mycoplasma pneumoniae infection. There was no difference in seroconversion rates between group 1 (five patients) and group 2 (six patients). There was a weak association between viral seroconversion and the isolation of Pseudomonas aeruginosa from sputum, though this was not significant.

\section{Introduction}

Bacteria, most notably Pseudomonas aeruginosa, are considered to be the most important cause of respiratory exacerbations in patients with cystic fibrosis. ${ }^{12}$ The role of infection with viruses, Mycoplasma pneumoniae, Coxiella burnetii, Chlamydia psittaci, and Legionella pneumophila in the natural history of cystic fibrosis lung disease is unknown. The incidence of such infections has not been shown to be higher in patients with cystic fibrosis than in healthy controls. ${ }^{34}$ The consequences of these infections may be serious, however, ${ }^{45}$ and patients with cystic fibrosis are recommended to be immunised against influenza. ${ }^{67}$ Some $20 \%$ of respiratory exacerbations in cystic fibrosis may not be related to any of the common bacteria or viruses. ${ }^{8}$ Knowing the importance of these infective agents in causing clinical deterioration in patients with cystic fibrosis may contribute to the rational use of antibacterial treatment. Antiviral drugs such as acyclovir, amantadine, ribavirin, and ganci-

Address for reprint requests: Dr A K Webb, University of Manchester School of Medicine, Monsall Hospital, Manchester M10 8WR.

Accepted 13 June 1980 clovir might be appropriate adjuncts to treatment if a specific virus were identified. A prospective study was undertaken to determine the incidence of infections with viruses and atypical microorganisms in a group of patients with cystic fibrosis with an acute respiratory exacerbation and a group who had stable respiratory disease.

\section{Methods}

We studied 36 patients with cystic fibrosis ( 18 of them male), mean age 23.6 (range 17-32) years, for evidence of infection with viruses, $C$ psittaci, $C$ burnetii, $L$ pneumophila, and $M$ pneumoniae. Patients who presented with symptoms of an influenza like illness were studied. Nineteen patients had an increase in purulent sputum production, cough, or breathlessness over a 48 hour period accompanied by a fall in $\mathrm{FEV}_{1}$ of at least $15 \%$ from the value obtained when they were well one month earlier (group 1). The other 17 patients (group 2) were stable both clinically and in terms of lung function values when they entered the study. Both groups of patients were asked to contact the unit if they thought they had an infective exacerbation. We also studied 18 healthy hospital volunteers with no underlying pulmonary disease. The study started in 
October 1985 and finished in October 1986. Previous influenza vaccination was documented.

Nasopharyngeal aspirates, throat swabs, and samples of sputum and serum were collected from patients in group 1 when they presented with an exacerbation. A second serum sample was obtained two weeks later. Throat swabs and paired sera with a two week interval were tested when symptoms of an influenza like illness were reported subsequently by either group. The healthy volunteers provided a throat swab and a single serum specimen at the beginning of the study. Antibodies against influenza viruses $\mathbf{A}$ and $\mathbf{B}$, respiratory syncytial virus, adenovirus, cytomegalovirus, measles virus, mumps virus $\mathrm{S}$ and $\mathrm{V}, C$ psittaci, $C$ burnetii, and $M$ pneumoniae were determined by complement fixation. An indirect fluorescent antibody test was used to detect antibodies to $L$ pneumophila. Significant seroconversion was considered to have occurred when there was a fourfold increase in titre between paired serum samples. IgA reactive human rhinovirus 2 was determined by an enzyme linked immunosorbent assay (ELISA). Where appropriate, $M$ pneumoniae specific IgM was measured.

Four cell lines (Hep-2 cells, MRC-5 cells, rolled monkey cells, primary human embryonic kidney cells) were used for isolation of viruses. Nasopharyngeal aspirates were processed and stained with monoclonal antibodies against influenza viruses $\mathbf{A}$ and $\mathbf{B}$ and respiratory syncytial virus. ${ }^{9}$ Adenovirus was detected by the direct immunofluorescence technique. In addition, aspirates were examined for parainfluenza viruses 1 and 3, cytomegalovirus, and measles virus by the indirect immunofluorescence technique.

The $\chi^{2}$ test was used for statistical analysis.

\section{Results}

Patients in group 1 attended on 73 (mean 3.8, range 29) occasions compared with 19 for group 2 patients (mean $1 \cdot 1$, range $1-2$ ). Group 1 patients had a mean $2 \cdot 6$ (range 1-4) exacerbations and group 2 a mean $1 \cdot 1$ (0-2). The mean (SEM) FEV 1 was $1.18(0 \cdot 12) 1$ for group 1 and $2.13(0.18) 1$ for group $2(\mathrm{p}<0.001)$; the FVC was $2.46(0.24) 1$ for group 1 and $3.10(0.19) 1$ in group $2(\mathrm{p}<0.01)$.

Seroconversion occurred in five patients of group 1 and in six of group 2. A single serum sample from the 18 healthy volunteers had a measles antibody titre (1/512) suggesting recent infection. Human rhinovirus 2 , influenza virus $\mathrm{A}$ and $\mathrm{B}$, cytomegalovirus, $M$ pneumoniae, and adenovirus were identified by serology in both groups of patients with cystic fibrosis (table 1). Coxsackie virus B5 was isolated from the throat swab of one patient in group 2 and the herpes simplex virus from a healthy volunteer. There was no significant difference in viral seroconversion rates
Table 1 Infective agents identified

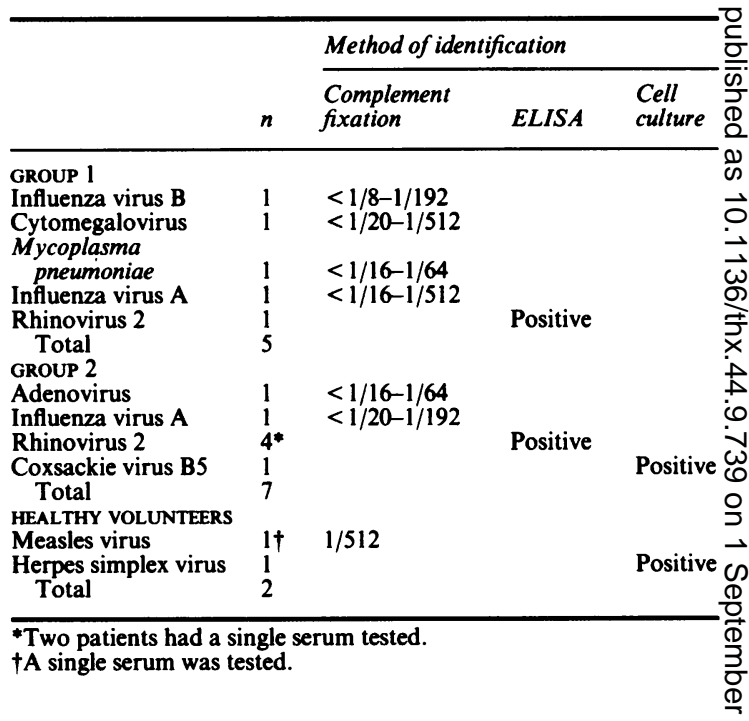

between groups 1 and 2 . The principal bacterial $\vec{\oplus}$ pathogens in sputum from both groups were $P_{0}^{\infty}$ aeruginosa, $P$ cepacia, Haemophilus influenzae, and Staphylococcus aureus (table 2). Ten of the 28 patients with Pseudomonas species isolated from their sputum had evidence of viral seroconversion, compared with only one of the patients with $S$ aureus, suggesting a $\frac{O}{\Phi}$ weak association between viral seroconversion rate $\stackrel{\varrho}{\Rightarrow}$ and pseudomonas infection $(p<0 \cdot 10)$.

No demonstrable titres of $L$ pneumophila antibody were found and immunofluorescent studies of the nasopharyngeal secretions were negative both in patients with cystic fibrosis and in controls.

Three patients with cystic fibrosis had influenza $\frac{O}{\mathcal{O}}$ vaccination less than a year before entry to the study $\underset{-}{x}$ period but none had detectable antibodies by the 3

Table 2 Seroconversion rates and principal bacterial pathogens in sputum of patients with cystic fibrosis in the patients of groups 1 and 2

\begin{tabular}{|c|c|c|c|c|}
\hline \multirow[b]{2}{*}{ Bacterial pathogens } & \multicolumn{2}{|c|}{$\begin{array}{l}\text { Number with } \\
\text { pathogen }\end{array}$} & \multicolumn{2}{|c|}{$\begin{array}{l}\text { Number with } \\
\text { seroconversion }\end{array}$} \\
\hline & Group 1 & Group 2 & Group 1 & Group 2 \\
\hline $\begin{array}{l}\text { Pseudomonas aeruginosa } \\
P \text { cepacia } \\
\text { Haemophilus influenzae } \\
\text { Staphylococcus aureus } \\
P \text { aeruginosa and } S \text { aureus } \\
P \text { aeruginosa and } \\
H \text { infuenzae } \\
P \text { aeruginosa, } S \text { aureus and } \\
H \text { influenzae } \\
S \text { aureus and } H \text { influenzae } \\
\text { Total }\end{array}$ & $\begin{array}{r}10 \\
4 \\
0 \\
0 \\
2 \\
2 \\
0 \\
0 \\
1 \\
19\end{array}$ & $\begin{array}{r}3 \\
1 \\
1 \\
1 \\
3 \\
1 \\
1 \\
2 \\
5 \\
17\end{array}$ & $\begin{array}{l}1 \\
2 \\
0 \\
0 \\
1 \\
1 \\
0 \\
0 \\
5\end{array}$ & $\begin{array}{l}2 \\
1 \\
0 \\
1 \\
1 \\
1 \\
0 \\
0 \\
6\end{array}$ \\
\hline
\end{tabular}


complement fixation test. The two patients with significant seroconversion for influenza virus $A$ and $B$ had never been vaccinated.

\section{Discussion}

The number of infections with respiratory viruses and atypical microorganisms did not differ significantly in patients with cystic fibrosis between those with and those without an acute exacerbation of respiratory symptoms. This contrasts with previous studies, ${ }^{10-13}$ where significant associations between viral and atypical infections and deterioration in the pulmonary function and clinical condition were documented. The paucity of isolations of viruses in our study, however, confirms the findings of other investigators. ${ }^{112}$ The higher age group of our subjects may have contributed as virus isolation and incidence rates are inversely related to age..$^{14}$ Another possibility is that an unidentified substance in the secretions in cystic fibrosis interferes with virus culture.

Eleven of the 36 patients had evidence of seroconversion for influenza virus $A$ and $B$, cytomegalovirus, adenovirus, and human rhinovirus 2 and this is in line with the incidence in previous reports, ${ }^{48}$ which has ranged from $20 \%$ to $39 \%$. Our study included human rhinovirus 2 whereas other studies did not. Four patients in group 2 and one in group 1 had a positive IgA ELISA result for human rhinovirus 2, indicating infection within the previous two months. It may reflect a lack of effect of rhinoviruses, a cause of respiratory deterioration in asthma and chronic bronchitis, on pulmonary deterioration in cystic fibrosis.

Absence of $L$ pneumophilia antibody titres contrasts with the findings of a previous study, ${ }^{12}$ where $17 \%$ of patients with cystic fibrosis studied over four months had demonstrable titres of $1 / 32$ or more.

Twenty eight patients had Pseudomonas species isolated from their sputum during the study. The incidence of pseudomonas isolations was higher in group 1 and only one patient without pseudomonas infection had evidence of seroconversion. This apparent relation between viral and atypical infections and pseudomonas related exacerbations supports the results of other studies. ${ }^{8}$

The absence of detectable antibodies to influenza virus in the three previously immunised patients may be due to the relatively insensitive complement fixation test. ${ }^{15}$ In a study of reactogenicity, immunogenicity, and the protective efficacy of influenza vaccine ${ }^{16}$ in children, including 83 with cystic fibrosis, there were five vaccine failures (less than a fourfold increase in antibody titre) in those with cystic fibrosis compared with only two in those without cystic fibrosis. More studies are needed to investigate the protective efficacy of vaccines currently used against respiratory viruses in patients with cystic fibrosis.
Development of techniques for rapid diagnosis of viral respiratory infections in patients with cystic fibrosis deserves a high priority. The serological methods used in our study provided the highest diagnostic yield but there is a delay of two weeks before significant seroconversion takes place. Immunofluorescence staining techniques with monoclonal antibodies using nasopharyngeal secretions is a method that could give rapid diagnosis of viral infections, ${ }^{9}$ but no positive results emerged from our study.

This study was partially supported by a grant from the Cystic Fibrosis Trust Fund. We thank Miss Caroline Dearden, MRC Common Cold Unit, for carrying out the rhinovirus serology.

\section{References}

1 May JR, Herrick NC, Thompson D. Bacterial infection in cystic fibrosis. Arch Dis Child 1972;47:908-13.

2 Hoiby N. Pseudomonas aeruginosa infection in cystic fibrosis. Diagnostic and prognostic significance of $P$ aeruginosa precipitins. Acta Pathol Microbiol Scand 1977;262, Sect C (suppl):3-96.

3 Deforest H, Grosz H, Larayu-Cussay L, Gregory JB, Satz J, Huang HH. The association of viral and mycoplasma infections with lower respiratory tract disease in patients with cystic fibrosis. Pediatr Res 1973;6:388.

4 Huang NN, Van Loon EL, Sheng KT. The flora of the respiratory tract of patients with cystic fibrosis. $J$ Pediatr 1961;59:512-21.

5 Andersen DH. Cystic fibrosis of the pancreas. J Chron Dis 1958;7:58-90.

6 American Academy of Pediatrics. Report of the Committee on Infectious Diseases. 17th ed. Philadelphia: Evanston, 1974:140.

7 Marks MI. Respiratory viruses in cystic fibrosis [editorial]. $N$ Engl J Med 1984;311:1695-6.

8 Petersen NT, Hoiby N, Mordhorst CH, Lind K, Flensborg EW, Brunn B. Respiratory infections in cystic fibrosis patients caused by virus, chlamydia and mycoplasma-possible synergism with Pseudomonas aeruginosa. Acta Paediatr Scand 1981;70:623-8.

9 Freke A, Stott EJ, Roome APCH, Caul EO. The detection of respiratory syncytial virus in nasopharyngeal aspirates: assessment formulation and evaluation of monoclonal antibodies as a diagnostic reagent. $J$ Med Virol 1986;18:181-91.

10 Wright PF, Khaw KT, Oxman MN, Shwachman H. Evaluation of the safety of amantadine and the role of respiratory viral infections in children with cystic fibrosis. J Infect Dis 1976;134:144-9.

11 Deforest A, Grosz HC, Laraya-Cuasay LR, Huang NN. A serologic study of mycoplasma pneumonia and respiratory syncytial virus infections in patients with cystic fibrosis. In: Cystic Fibrosis Club abstracts. Atlanta: Cystic Fibrosis Foundation, 1976:31.

12 Efthimiou J, Hodson ME, Taylor P, Taylor AG, Batten JC. Importance of viruses and Legionella pneumophila 
in respiratory exacerbations of young adults with cystic fibrosis. Thorax 1984;39:150-4.

13 Wang EEL, Prober GC, Manson B, Corey M, Levison H. Association of respiratory viral infections with pulmonary deterioration in patients with cystic fibrosis. $N$ Engl J Med 1984;311:1653-8.

14 Cooney MK, Hall CE, Fox JP. The Seattle virus watch. III. Evaluation of isolation methods and summary of infections detected by viral isolations. Am J Epidemiol 1972;96:286-305.

15 Grilli EA, Smith AJ. The use of a radial haemolysis test for neuraminidase antibodies in the diagnosis of influenza A infection. J Hyg (Camb) 1983;91:147-56.

16 Gross PA, Ennis FA, Gaerlan PF, Denson LJ, Denning CR, Schiffman D. A controlled double blind comparison of reactogenicity, immunogenicity and protective के efficacy of whole-virus and split-product influenza vaccine in children. $J$ Infect Dis 1977;136:623-32. 